\title{
Notkun vímuefna í æð: Afdrif sjúklinga eftir innlögn á gjörgæslu og niðurstöður réttar- efnafræðilegra rannsókna við andlát
}

Kristinn Sigvaldason ${ }^{1}$ læknir, Póroddur Ingvarsson ${ }^{1}$ læknir, Svava Pórðardóttir² lyfja- og eiturefnafræðingur,

Jakob Kristinsson ${ }^{3}$ prófessor emeritus, Sigurbergur Kárason ${ }^{1,3}$ læknir

\section{ÁGRIP}

Inngangur: Notkun vímuefna í æð er alpjóðlegt vandamál sem hefur alvarlegar afleiðingar fyrir neytandann og samfélagið í heild. Markmið rannsóknarinnar var að skoða tvennt varðandi alvarlegustu afleiðingar neyslu vímuefna í æð: afdrif peirra sem purftu að leggjast inn á gjörgæslu og réttarefnafræðilegar skýrslur um andlát eftir neyslu vímuefna í æð. Efniviður og aðferðir: Kannaðar voru allar innlagnir á gjörgæsludeild Landspítala sem tengdust notkun vímuefna í æð á tímabilinu 2003-2007 og metin 5 ára lifun. Einnig var farið yfir réttarefnafræðilegar skýrslur vegna dauðsfalla einstaklinga með sögu um notkun vímuefna í æð á sama tímabili.

Niðurstöður: Alls reyndust 57 einstaklingar hafa sögu um notkun vímuefna í æð við innlögn á gjörgæsludeild á tímabilinu, sem er um 1\% af heildarfjölda innlagna. Innlagnir voru oftast vegna eitrunar (52\%) eða lífs- hættulegrar sýkingar (39\%). Miðgildi aldurs var 26 ár og 66\% voru karlar. Eitranir voru algengastar, oftast vegna misnotkunar á lyfseðilsskyldum lyfjum. Dánartíðni á sjúkrahúsi var 16\% og 5 ára dánartíđni 35\%. Meðaltími frá útskrift að andláti var $916 \pm 858$ dagar. Alls fundust 38 krufningarskýrslur einstaklinga með sögu um notkun vímuefna í æð á tímabilinu, eða 4,1/105/ár fyrir aldurshópinn 15-59 ára. Algengasta dánarorsök var eitrun (53\%) sem oftast var vegna misnotkunar á lyfseðilsskyldum lyfjum (90\%) og oft voru mörg efni tekin samtímis.

Ályktun: Lífslíkur einstaklinga sem nota vímuefni i æð og hafa purft gjörgæsluinnlögn eru verulega skertar. Áhyggjuefni er hve algengt er að nota lyfseðilsskyld lyf við slíka neyslu. Umfang vandans virðist svipað og á öðrum Norðurlöndum.
Fyrirspurnir: Kristinn Sigvaldason krisig@landspitali.is

Greinin barst 14. mars 2014 sampykkt til birtingar 8. september 2014.

\section{Inngangur}

Heilsufarsleg vandamál tengd notkun ávana- og fíkniefna eru vel pekkt um allan heim en sjúkdómsbyrði af slíkri neyslu er mest hjá peim sem sprauta sig í æð. Jafnframt er dánartíðni hjá slíkum neytendum há og óvænt dauðsföll tengjast að jafnaði ofskammti lyfja eða sjálfsvígum. ${ }^{1}$ Flest faraldsfræðileg gögn um pessi vandamál byggja á áætlunum, erfitt er að nálgast nákvæmar upplýsingar par sem ekki koma öll tilfelli til kasta heilbrigðiskerfis eða opinberra aðila og vandamálið pví að nokkru falið. Áætlað er að 11-21 milljón manns noti vímuefni í æð í heiminum. ${ }^{1}$ Samkvæmt ársskýrslum SÁÁ er talið að um 700 manns noti vímuefni í æð hér á landi og samkvæmt pví ætti algengi að vera 3,5/1000 íbúa 15-64 ára. ${ }^{2}$ Petta er svipað og birt hefur verið fyrir Danmörku (4,4/1000 íbúa 15-64 ára) og Noreg (3,3/1000 íbúa 15-64 ára). ${ }^{3}$ Pessar tölur byggja á tíðni innlagna vegna vímuefnanotkunar en ná ekki til peirra sem misnota lyf og tengjast ekki heilbrigðiskerfinu. Vandamálið er pví hugsanlega viðameira. Mikilvægt er að afla upplýsinga um pennan hóp einstaklinga hér á landi svo hægt verði ao átta sig á umfangi vandans.

Par sem flestir sem fá verulega alvarlega fylgikvilla vegna vímuefnanotkunar í æð koma til innlagnar á gjörgæsludeildir Landspítala gefur pað möguleika á að nálgast upplýsingar um pann hóp og kanna horfur peirra, en slík samantekt hefur ekki verið gerð áður hér á landi.

Réttarkrufning er að jafnaði gerð pegar andlát eru talin tengjast misnotkun ávana- og fíkniefna og öll lífsýni sem tekin eru við slíkar krufningar eru send á Rannsóknastofu í lyfja- og eiturefnafræði til greiningar. Úr skýrslum rannsóknastofunnar er pví hægt að afla upplýsinga um fjölda látinna einstaklinga sem nota vímuefni í æð og dánarorsakir peirra.

Markmið rannsóknarinnar var að afla upplýsinga um alvarlegustu afleiðingar notkunar vímuefna í æð frá tveimur sjónarhornum: Í fyrsta lagi með pví að kanna horfur peirra einstaklinga sem höfðu lagst inn á gjörgæsludeild Landspítala vegna afleiðinga neyslu vímuefna í æð á 5 ára tímabili og í öðru lagi að fara yfir réttarefnafræðilegar skýrslur einstaklinga með sögu um notkun vímuefna í æð sem höfðu látist á sama tímabili og fá pannig fram dánartíðni.

\section{Efniviður og aðferðir}

Rannsóknin var afturskyggn og skipt í tvo hluta. Framkvæmd hennar var sampykkt af framkvæmdastjóra lækninga á Landspítala, Vísindasiðanefnd (08049), Persónuvernd og Dánarmeinaskrá Hagstofu Íslands. 


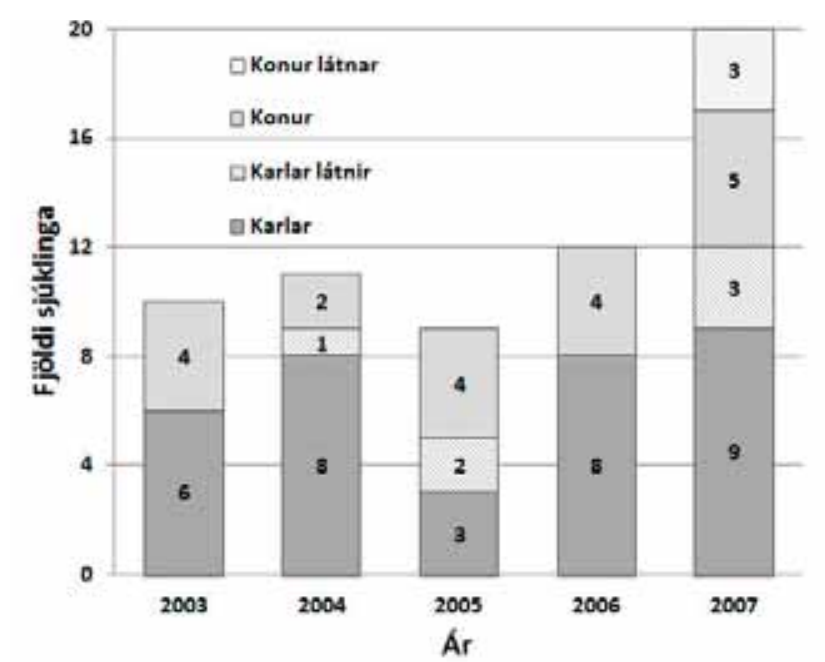

Mynd 1. Innlagnir á gjörgæsludeild vegna fylgikvilla vímuefnanotkunar í æð árin 2003 til 2007. Sýndur er fjöldi sjúklinga, kynjadreifing og fjöldi látinna fyrir hvert ár.

\section{Innlagnir á gjörgæsludeild}

Farið var afturskyggnt yfir innlagnarskrár allra sjúklinga sem legið höfðu á gjörgæsludeildum Landspítalans árin 2003-2007 og leitað upplýsinga um hugsanlega vímuefnanotkun. Ef grunur vaknaði um slíkt voru sjúkraskrár einnig yfirfarnar. Leitað var upplýsinga um sjúklinga sem höfðu verið lagðir inn vegna eituráhrifa af vímuefnum, svo sem meðvitundarleysis, öndunarbilunar eða blóðrásarbilunar, en einnig vegna óbeinna áhrifa vímuefnanotkunar, svo sem sýkingar eða fjöláverka. Safnað var upplýsingum um aldur, kyn, ástæðu innlagnar, vímuefni sem notuð voru, legutíma á sjúkrahúsi, gjörgæslumeðferð, sjúkdómsgreiningu og afdrif. Einnig voru skráð APACHE II stig (Acute Physiology and Chronic Health Evaluation) einstaklinga, en pað er stigunarkerfi fyrir sjúkdómsástand sjúklinga við innlögn á gjörgæsludeild og gerir samanburð milli einstaklinga og sjúklingahópa mögulegan. ${ }^{17}$ Til að kanna langtímahorfur var farið yfir sjúkraskrár einstaklinga í lok ársins 2012 og kannað hvort peir væru lifandi eða látnir. Upplýsinga um dánarorsök var aflað úr Dánarmeinaskrá Hagstofu Íslands. Haft var samband við gjörgæslulækna Fjórðungssjúkrahússins á Akureyri varðandi innlagnir á gjörgæsludeild par í tengslum við notkun vímuefna í æð en að mati peirra hafði ekki verið um slíkar innlagnir að ræða á rannsóknartímabilinu.

\section{Réttarefnafræđilegar rannsóknir}

Farið var yfir niðurstöður réttarefnafræðilegra rannsókna á Rannsóknastofu í lyfja- og eiturefnafræði á árunum 2003-2007 og greindir einstaklingar par sem grunur var um notkun vímuefna í æð. Vísbendingar sem stuðst var við voru stunguför greind við krufningu, sprautur á vettvangi andláts, pekkt saga um vímuefnanotkun í æð, ólögleg ávana- og fíkniefni greind í lífsýnum, metadon greint í lífsýnum, greind lifrarbólga $C$ og andlát í fangelsi. Kannað var hvort pessir einstaklingar hefðu skráðar innlagnir á Landspítala og pá farið yfir sjúkraskrár peirra varðandi pær innlagnir. Upplýsingar um dánarorsök var fengin úr Dánarmeinaskrá Hagstofu Íslands.
Niðurstöður lyfjamælinga voru skráðar og voru lyf, vímu- og eiturefni flokkuð á sama hátt og gert hefur verið í samnorrænum rannsóknum á dauðsföllum vímuefnaneytenda $\mathrm{a}^{4-7}$ en pað er byggt á flokkunarkerfi International Narcotics Control Board og er eftirfarandi:

Flokkur I: Kókaín, fentanýl, heróín/morfín, metadon, kódein og tramadól.

Flokkur II: Amfetamín, metamfetamín, MDMA (ecstasy), metýlfenídat og tetrahýdrókannabínól.

Flokkur III: Benzódíazepín, karísópródól/mepróbamat og zolpídem.

Flokkur IV: Öll önnur lyf og eiturefni, par með talið etanól.

Ef um mörg efni var að ræða var pað efni sem hafði lægsta flokkunartölu talið orsök andláts, í samræmi við fyrri rannsóknir sem stuðst hafa við petta flokkunarkerfi.

\section{Tölfræð}

Upplýsingum var safnað í Microsoft Excel tölvuforritið (Microsoft Corporation, Seattle, USA) og notast við lýsandi tölfræði. Niðurstöður eru birtar sem fjöldi, hlutföll, meðaltal ( \pm staðalfrávik) og miðgildi (25.:75. hundraðsmark, bil).

Horfur einstaklinga eftir legu á gjörgæsludeild voru bornar saman við dánartíðni aldurshóps 20-39 ára í pjóðfélaginu (www. statice.is), sem samsvarar til meðalaldurs rannsóknarhópsins \pm eitt staðalfrávik.

Dánartíðni samkvæmt réttarfræðilegum rannsóknum á andlátum tengdum vímuefnanotkun í æð var reiknuð sem fjöldi látinna á hverja $10^{5}$ íbúa á aldursbilinu 15-59 ára. Upplýsingar umfjölda íbúa á aldrinum 15-59 voru fengnar frá Hagstofu Íslands (www.statice. is). Notast var við petta aldursbil til pess að auðvelda samanburð við sambærilegar erlendar rannsóknir. ${ }^{4-7}$

\section{Niðurstöður}

\section{Innlagnir á gjörgæsludeild}

Á rannsóknartímabilinu var árlegur meðalfjöldi innlagna á gjörgæsludeildir Landspítala 1280. Meðaltal APACHE II stiga við innlögn var 12,5 og dánarhlutfall var 7,5\%. Alls reyndust 62 gjörgæsluinnlagnir tengjast vímuefnanotkun í æð. Petta samsvarar 12,4 innlögnum á ári að meðaltali, eða um 1\% allra gjörgæsluinnlagna á Landspítala. Tveir einstaklingar voru tvisvar lagðir inn og einn einstaklingur fjórum sinnum. Heildarfjöldi einstaklinga var pví 57. Hægt var að nálgast sjúkraskýrslur allra sjúklinga og kanna afdrif peirra. Karlar voru 36 (63\%) og konur 21 (37\%). Meðalaldur innlagðra var $29 \pm 9$ ár og miðgildi aldurs var 26 ár (22:35, bil 1850). Miðgildi APACHE II stiga var 12 (8:15, bil 0-33). Eins og sést á mynd 1 voru innlagnir flestar árið 2007 (n=20, 32\%) og fæstar árið 2005 (n=9, 15\%). Meðallegutími á gjörgæsludeild var $3 \pm 5$ dagar og miðgildi legutíma var einn dagur (1:3, bil 1-28).

Algengasta innlagnarástæða var eitrun $(n=32,52 \%)$, annaðhvort fyrir slysni ( $\mathrm{n}=21,34 \%)$ eða í sjálfsvígstilgangi ( $\mathrm{n}=11,18 \%)$. Notkun margra lyfja samtímis var algeng. Helstu vímuefnin voru ópíöt í 14 tilfellum (45\%), amfetamín eða metýlfenídat í 5 tilfellum (16\%) og kókaín í premur tilfellum (9\%). Hjá 9 sjúklingum (29\%) kom ekki fram í sjúkraskýrslu hvaða lyf höfðu verið notuð par sem peir vissu pað ekki sjálfir eða vildu ekki gefa pað upp.

Lyf af flokki ópíata voru oftast lyfseðilsskyld lyf, morfíntöflur (Contalgin®) uppleystar og notaðar til inndælingar og verkja- 
plástrar (fentanýl, Durogesic ${ }^{\circledR}$ ) einnig uppleystir og notaðir til inndælingar.

Alvarleg sýking var innlagnarástæða í 24 tilfellum (39\%) og má par nefna sýklasótt $(n=11,18 \%)$, hjartapelsbólgu $(n=7,11 \%)$, sýkingu í miðtaugakerfi $(n=3,5 \%)$ og lungnabólgu $(n=3,5 \%)$.

Fjöláverki var ástæða innlagnar í 5 tilfellum (8\%). Í öllum tilfellum var um ofbeldisáverka að ræða, höfuðáverki í einu tilfelli, kviðarholsáverki í premur tilfellum og brjóstholsáverki í einu tilfelli. Ein innlögn var vegna sykursýkislosts.

Pörf var á meðferð í öndunarvél í 30 tilfellum (48\%) og nota purfti æðavirk lyf vegna losts í 13 tilfellum (23\%).

Alls létust 9 einstaklingar í sjúkrahúslegu, allir á gjörgæsludeild, og dánarhlutfall pví 16\%, meirihlutinn voru karlar $(\mathrm{n}=6)$. Dánarorsakir voru heilaskaði $(n=2)$, hjartapelsbólga $(n=2)$, heilahimnubólga $(n=1)$, fjöláverki $(n=2)$ og fjölkerfabilun $(n=2)$.

Alls útskrifuðust 48 einstaklingar af gjörgæsludeild og síðar af sjúkrahúsi. Fimm ára eftirfylgni leiddi í ljós að 11 peirra létust eftir sjúkrahúsleguna, eða 19\% peirra sem höfðu purft gjörgæslumeðferð. Fimm ára dánarhlutfall peirra sem purfa gjörgæsluinnlögn vegna notkunar vímuefna í æð er pví 35\%. Mynd 2 sýnir KaplanMeier graf með langtímahorfum rannsóknarhópsins í samanburði við viðmiðunarhóp sem hefur dánarhlutfall 0,04\% á ári. Meðaltími frá útskrift af sjúkrahúsi að andláti var $916 \pm 858$ dagar og miðgildi 794 dagar (210:1410, bil 21-2753)

\section{Réttarefnafræðilegar rannsóknir}

Á rannsóknartímabilinu létust alls 38 einstaklingar par sem hægt var að finna tengsl við notkun vímuefna í æð. Petta samsvarar 4,1 tilfellum/105/ár í aldurshópnum 15-59 ára, eða um 1,1\% af áætluðum fjölda peirra sem nota vímuefni í æð á Íslandi á ári. Af peim létust 9 á sjúkrahúsi, allir á gjörgæsludeild, einsog fyrr var rakið, og 29 utan sjúkrahúss. Ekki var gerð réttarkrufning vegna 6 dauðsfalla á sjúkrahúsi par sem dánarorsök var talin pekkt, en í öllum hinum tilfellunum var gerð réttarkrufning $(n=32,84 \%)$. Meðalaldur var $34 \pm 10$ ár og miðgildi aldurs 34 ár (25:43, bil 1852). Karlar voru nokkru fleiri og eldri $(\mathrm{n}=24(63 \%)$, miðgildi aldurs 38 ár, 25:44, bil 15-52) en konur ( $n=14$, (37\%), miðgildi aldurs 32 ár, 28:39, bil 20-47).

Allir höfðu áður komið á bráðamóttöku og 5 peirra (13\%) höfðu legið á gjörgæsludeild á rannsóknartímabilinu. Miðgildi tímalengdar frá komu á bráđamóttöku að dánardegi var 92 dagar (18:230, bil 3-1545). Reynt hafði verið að endurlífga 13 einstaklinganna (34\%).

Banvæn eitrun var réttarefnafræðilega staðfest dánarorsök í 20 tilfellum (53\%). Aðrar dánarorsakir samkvæmt dánarvottorðum voru sjálfsvíg með öðrum aðferðum en eitrun ( $n=5,13 \%)$, manndráp $(n=2,5 \%)$, skorpulifur $(n=3,8 \%)$, geðsjúkdómar $(n=2,5 \%)$, bráð hjartapelsbólga $(n=2,5 \%)$, fjöláverki $(n=1,3 \%)$, flog $(n=1,3 \%)$, heilahimnubólga $(n=1,3 \%)$ og krabbamein $(n=1,3 \%)$. Miðgildi aldurs peirra sem létust vegna eitrunar var 34 ár (25:44, bil 22-53), karlar voru 12 (60\%) og konur voru 8 (40\%). Algengast var að efni af flokki I væru metin meginorsök banvænnar eitrunar eða í $85 \%$ tilfella, morfín $(n=10)$, metadón $(n=2)$, fentanýl $(n=1)$, tramadól $(n=1)$ og kódein $(n=1)$. Efni af öðrum flokkum voru kókaín $(n=2)$, metýlfenídat $(n=2)$ og amitriptylín $(n=1)$. Lyfseðilsskyld lyf voru pannig helsti eitrunarvaldurinn í öllum tilvikum nema tveimur.

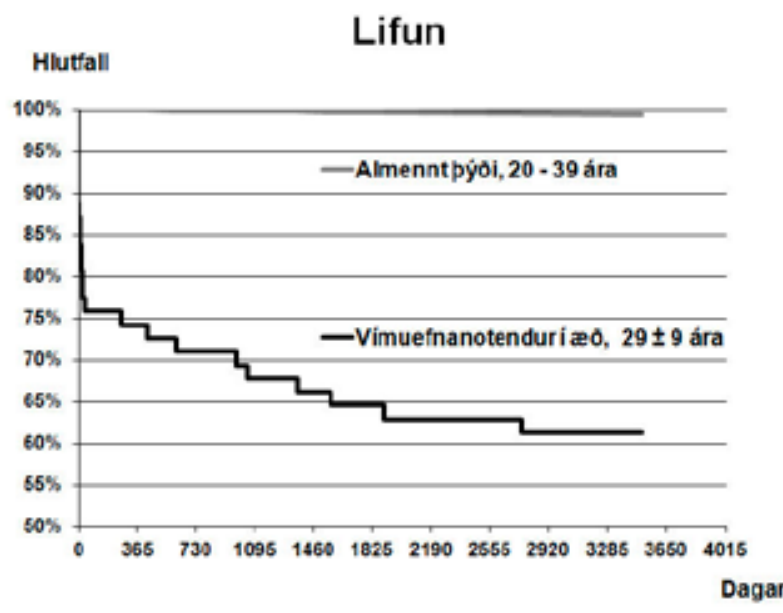

Mynd 2. Lifun vímuefnanotenda í æð sem purft hafa meðferð á gjörgæsludeild samanburði við almennt pýði, sýnt með Kaplan-Meier grafi. Eftirfylgni var frá ársbyrjun 2003 til ársloka 2012.

Tafla I sýnir niðurstöður allra lyfjamælinga í blóði peirra 20 einstaklinga sem létust vegna eitrunar. Notkun nokkurra efna samtímis var algeng. Alls voru greind 29 mismunandi efni í blóði, að meðaltali fjögur (bil 2-6) hjá hverjum einstaklingi. Oftast var um að ræða amfetamínskyld efni, ópíöt og benzódíazepínlyf.

\section{Umræða}

Í pessari rannsókn er lýst alvarlegum afleiðingum neyslu vímuefna í æð frá tveimur sjónarhornum til að fá sem fyllsta mynd af pessu

Tafla I. Réttarefnafræðilegar rannsóknir á andlátum tengdum vímuefnanotkun í æð. Taflan sýnir niðurstöður mælinga hjá 20 einstaklingum með banvæna eitrun.

\begin{tabular}{|c|c|c|c|}
\hline & Lyf & $\mathrm{N}$ & $\%$ \\
\hline \multirow[t]{7}{*}{ Flokkur I } & Morfín & 10 & 12,2 \\
\hline & Metadon & 2 & 2,4 \\
\hline & Kódein & 3 & 3,7 \\
\hline & Kókaín & 5 & 6,1 \\
\hline & Fentanýl & 1 & 1,2 \\
\hline & Tramadól & 1 & 1,2 \\
\hline & alls & 22 & 26,8 \\
\hline \multirow[t]{6}{*}{ Flokkur II } & Amfetamín & 14 & 17,1 \\
\hline & Metamfetamín & 1 & 1,2 \\
\hline & MDMA & 3 & 3,7 \\
\hline & Metýlfenídat & 5 & 6,1 \\
\hline & Tetrahýdrókannabínól & 1 & 1,2 \\
\hline & alls & 24 & 29,3 \\
\hline \multirow[t]{4}{*}{ Flokkur III } & Benzódíazepín & 14 & 17,1 \\
\hline & Zolpídem & 1 & 1,2 \\
\hline & Karísópródól/mepróbamat & 1 & 1,2 \\
\hline & alls & 16 & 19,5 \\
\hline \multirow[t]{3}{*}{ Flokkur IV } & Etanól & 3 & 3,7 \\
\hline & Önnur lyf & 17 & 20,7 \\
\hline & alls & & 20,0 \\
\hline Alls & & 82 & 100,0 \\
\hline
\end{tabular}


alvarlega vandamáli. Lífslíkur peirra sem purft hafa á gjörgæsluinnlögn að halda í tengslum við notkun vímuefna í æð er mjög skert en 35\% peirra eru látnir innan 5 ára. Réttarefnafræðilegar rannsóknir sem gerðar eru í tengslum við andlát einstaklinga með sögu um notkun vímuefna í æð sýna að heildardánartíðni er 4,1 einstaklingar $/ 10^{5}$ /ár fyrir aldurshópinn 15-59 ára, sem er líkt og á hinum Norðurlöndunum. Bæði pessi sjónarhorn staðfesta algenga misnotkun lyfseðilsskyldra lyfja til inngjafar í æð hér á landi og er pað áhyggjuefni.

\section{Innlagnir á gjörgæesludeild}

Um 1\% allra innlagna á gjörgæsludeild Landspítala tengist notkun vímuefna í æð. Um er að ræða unga einstaklinga, flestir undir prítugu, sem eru alvarlega veikir samkvæmt APACHE II stigunarkerfinu, með lífshættulegar eitranir, sýkingar eða áverka eftir ofbeldi. Algengt er að peir purfi meðferð með öndunarvél og æðavirkum lyfjum. Dánarhlutfall er hátt í sjúkrahúslegu (16\%) og 5 ára lífslíkur verulega skertar (65\%). Helmingur andlátanna átti sér stað innan priggja ára frá útskrift af sjúkrahúsi sem endurspeglar alvarleika fíknisjúkdómsins pegar hann hefur leitt til gjörgæsluinnlagnar. Algengasta dánarorsök er eitrun, oftast vegna sterkra verkjalyfja en notkun margra lyfja samtímis var algeng. Flest lyfjanna sem notuð voru eru lyfseðilsskyld, oftast morfíntöflur sem leystar voru upp og notaðar til inndælingar.

Pessar niðurstöður vekja spurningar um starfshætti og eftirlit við ávísun slíkra lyfja og hvort grípa megi frekar inn hjá einstaklingum sem vistast hafa á gjörgæslu í tengslum við notkun vímuefna í æð og pví í aukinni áhættu á ótímabæru andláti. Almennt er talið að áhættuminnkandi aðgerðir geti skilað árangri meðal pessara einstaklinga en ekki er ljóst hvernig slíkum aðgerðum væri best háttað. ${ }^{8}$

\section{Niðurstöður réttarefnafræðilegra rannsókna}

Andlát 38 einstaklinga sem tengdust notkun vímuefna í æð komu til réttarefnafræðilegrar rannsóknar á rannsóknartímabilinu. Petta samsvarar 4,1 á hverja 100.000 íbúa á aldrinum 15-59 ára. Par af létust 20 af völdum eitrunar eða 2,2 á hverja 100.000 íbúa í pessum aldurshópi. Dánartíðni af völdum eitrunar meðal fíkniefnaneytenda hefur áður verið könnuð hér á landi sem hluti af samnorrænum rannsóknum. Dánartíðni á Norðurlöndum reyndist vera 2,6 árið 19914, 1,20 árið 19975 3,6 árið 20026 og 4,6 árið $2007^{7}$ á hverja 100 púsund íbúa á aldrinum 15-59 ára sem er svipað og fram kemur í pessari rannsókn. Dánartíðnin virðist vera að hækka á Norðurlöndum en stendur í stað eða fer jafnvel lækkandi almennt í Evrópu. ${ }^{9}$ Samkvæmt niðurstöðum pessarar rannsóknar virtist dánartíðni á Íslandi vera hækkandi á tímabilinu (8,0/105/ár síðasta árið) með auknum fjölda gjörgæsluinnlagna og hækkandi dánarhlutfalli í sjúkrahúslegu, en fjöldi einstaklinga er ekki nægur til að draga frekari ályktanir af pví. Hlutfall kvenna virðist vera nokkuð hærra hér á landi (37\%) en á hinum Norðurlöndunum (15-20\%). ${ }^{4-7}$

Samkvæmt alpjóðlegum samantektum virðist dánarhlutfall eiturlyfjaneytenda á aldrinum 15 til 54 ára vera 1,12\% á ári. ${ }^{3}$ Pegar peir sem nota vímuefni í æð eru skoðaðir sérstaklega reynist árleg dánartíðni hjá peim vera milli 0,54\% og 2,3\%. ${ }^{10,11}$ Samkvæmt niðurstöðum pessarar rannsóknar er árleg heildardánartíðni hjá pessum hópi hérlendis um 1,1\% miðað við að um 700 slíkir neytendur séu hér á landi, sem er svipað og í fyrrnefndum rannsóknum. Pó ber að túlka pær tölur varlega par sem stuðst er við áætlun sem gerð er útfrá fjölda innlagna á meðferðarstofnun SÁÁ. Nákvæmari tala um heildarfjölda peirra sem nota vímuefni í æð á Íslandi er ekki pekkt par sem ætla má að ekki allir komi til meðferðar og vandamálið pannig að nokkru falið.

Á rannsóknartímabilinu létust alls 806 einstaklingar á Íslandi í aldurshópnum 15-54 ára, par af 71 í umferðarslysum eða 8,8\%.12 Banaslys í umferðinni eru talin marktæk orsök ótímabærra dauðsfalla hjá ungu fólki. Sambærileg tala fyrir pá sem nota vímuefni í æð og eru á sama aldri er 4,7\% sem verður einnig að teljast marktæk orsök ótímabærra andláta í pessum aldurshópi.

Samkvæmt upplýsingum frá Hagstofu Íslands áttu 7 manndráp sér stað á Íslandi á rannsóknartímabilinu en tveir einstaklingar innan rannsóknarhópsins létust af annarra völdum. Jafnframt áttu allir innan hópsins komu á bráðamóttöku og 5 höfðu legið á gjörgæslu. Lífi einstaklinga sem neyta vímuefna í æð er pví ógnað á margvíslegan hátt.

Lyf af flokki I voru meginorsök andláts 17 einstaklinga, par af var morfín algengast, sem er sambærilegt við niðurstöður rannsóknar frá Norðurlöndum árið 2007.7 Heróín er ekki algengt á íslenska fíkniefnamarkaðnum, lögreglan leggur hald á í mesta lagi örfá grömm árlega. ${ }^{13}$ Kókaíneitrun olli dauða í tveimur tilfellum en í öllum hinum var um að ræða lyfseðilsskyld lyf. Sú venja að leysa upp ávana- og fíknilyf í töfluformi eða plástrum virðist vera útbreidd meðal fíkniefnaneytenda hér á landi. Misnotkun á fentanýl verkjaplástrum er áhyggjuefni vegna gjörgæsluinnlagna og jafnvel dauða í rannsóknarhópnum. Petta er líka pekkt í nágrannalöndum og lögð áhersla á hættuna sem fylgir notkun slíkra efna. ${ }^{14}$ Notkun lyfseðilsskyldra lyfja virðist einnig vera vaxandi hjá yngri fíkniefnanotendum í Bandaríkjunum. ${ }^{15}$ Spurning er hvort slíkir neytendur geri sér grein fyrir hættunni af pví að nota lyfsseðilskyld lyf á pennan hátt og hvort mögulegt sé að auka fræðslu hvað pað varðar meðal almennings.

Réttarefnafræðileg rannsókn á blóðsýnum sýndi að notkun margra lyfja samtímis var algeng, að meðaltali fjögur lyf í hverju tilfelli. Samtímis notkun á örvandi efnum, kókaíni, tetrahýdrókannabínóli og lyfseðilskyldum lyfjum var algeng, bæði hjá einstaklingum sem lagðir voru inn á gjörgæsludeild og hjá peim sem létust utan sjúkrahúsa. Algengast var ao finna amfetamín í blóði peirra sem létust í tengslum við notkun vímuefna í æð, enda virðist pað vera algengasta efnið á fíkniefnamarkaðnum hér á landi. ${ }^{2}$ Metýlfenídat olli dauða í tveimur tilfellum, en pað er lyfseðilsskylt lyf af amfetamínflokki og virðist notkun pess fara vaxandi meðal fíkniefnaneytenda. Samkvæmt opinberum tölum fór sala pessa lyfs vaxandi á Íslandi á rannsóknartímabilinu, fjöldi seldra skammta (DDD) á hverja 1000 íbúa jókst úr 5,27 árið 2003 í 10,6 árið $2007^{16}$

Notkun lyfja af flokki III, aðallega benzódíazepínsambanda, virðist vera algeng meðal fíkniefnaneytenda hérlendis, en notkun peirra getur aukið hættu á milliverkunum og par með eituráhrifum sterkra verkjalyfja. Lyf af flokki IV eru aðallega geðlyf og greining peirra í blóðsýnum gefur til kynna að sumir einstaklinganna voru á meðferð vegna geðsjúkdóma.

Helstu veikleikar pessarar rannsóknar eru að hún er afturskyggn og ef til vill hafa ekki allir einstaklingar með sögu um notkun vímuefna í æð greinst samkvæmt skilyrðum um inntöku í rannsóknina. Örlögum fremur fárra einstaklinga er lýst, sem er 
eðlilegt hjá fámennri pjóð. Styrkleikar rannsóknarinnar eru peir að hún nær til flestra sem fengu lífshættulega fylgikvilla í tengslum við notkun vímuefna í æð og pörfnuðust gjörgæsluinnlagnar en erfitt er að fela slíka neyslu við pær aðstæður og eftirfylgni peirra var nákvæm. Einnig náði hún til allra niðurstaðna réttarefnafræðilegra rannsókna á dauðsföllum fólks sem vitað er um með tengsl við notkun vímuefna í æð á rannsóknartímabilinu.

\section{Ályktun}

Um 1\% innlagna á gjörgæsludeildir Landspítala er vegna fylgikvilla af neyslu fíkniefna í æð. Petta er ungur sjúklingahópur sem oftast leggst inn vegna alvarlegra eitrana eða sýkinga og er með mjög skertar lífslíkur miðað við sama aldurshóp, en 35\% hans voru látin innan 5 ára. Niðurstöður réttarefnafræðilegra rannsókna leiða í ljós 4,1 andlát/105/ár vegna neyslu vímuefna í æð sem gefur til kynna að umfang vandans sé sambærilegt og á öðrum Norðurlöndum. Áhyggjuefni er hve algengt er að nota uppleyst lyfseðilsskyld lyf sem vímuefni til inngjafar í æð.

\section{Heimildir}

1. Degenhardt L, Hall W. Extent of illicit drug use and dependence, and their contribution to the global burden of disease. Lancet 2012; 379: 55-70.

2. Ársskýrsla SÁÁ 2007-2010, saa.is - september 2014

3. Mathers BM, Degenhardt L, Phillips B, Wiessing L, Hickman M, Strathdee SA, et al. for the 2007 reference group to the UN on HIV and Injecting drug use. Global epidemiology of injecting drug use and HIV among people who inject drugs: a systematic review. Lancet 2008; 372: 1733-45.

4. Steentoft A, Teige B, Holmgren P, Vuori E, Kristinsson J, Kaa E, et al. Drug addict deaths in the Nordic countries: a study based on medico-legally examined cases in the five Nordic countries in 1991. Forensic Sci Int 1996; 77: 109-18.

5. Steentoft A, Teige B, Ceder G, Vuori E, Kristinsson J, Simonsen KW, et al. Fatal poisoning in drug addicts in the Nordic countries. Forensic Sci Int 2001; 123: 63-9.

6. Steentoft A, Teige B, Holmgren P, Vuori E, Kristinsson J, Hansen AC, Ceder G, et al. Fatal poisoning in Nordic drug addicts in 2002. Forensic Sci Int 2006; 160: 148-56.
7. Wiese Simonsen $K$, Normann PT, Ceder G, Vuori E, Thordardottir S, Thelander G, et al. Fatal poisoning in drug addicts in the Nordic countries in 2007. Forensic Sci Int 2011; 207: 170-6.

8. Jones L, Pickering L, Sumnall H, McVeigh J, Bellis MA. Optimal provision of needle and syringe programs for injecting drug users: A systematic review. Int J Drug Policy 2010; 21: 335-42.

9. Wiessing L, Klempová D, Hedrich D, Montanari L Gyarmathy VA. Injecting drug use in Europe: stable or declining. Euro Surveill 2010; 15: 19604

10. Frischer M, Bloor M, Goldberg D, Clark J, Green S, McKeganey N. Mortality among injecting drug users: a critical reappraisal. J Epidemiol Comm Health 1993; 47: 59-63.

11. Copeland L, Budd J, Robertson JR, Elton RA. Changing patterns in causes of death in a cohort of injecting drug users, 1980-2001. Arch Intern Med 2004; 164: 1214-20.

12. Rannsóknarnefnd samgönguslysa (áour Rannsóknarnefnd umferðaslysa). Banaslys í umferðinni. Skýrslur frá 20032007. ww2.rnu.is
13. Ríkislögreglustjóri. Afbrotatölfræði 2009; 24, tafla 6. Fíkniefni sem lögregla og tollgæsla lagði hald á árið 2004 til 2009. Reykjavík 2009.

14. Kronstand $\mathrm{R}$, Druid $\mathrm{H}$, Holmgren $\mathrm{P}$, Rajs J. A cluster of fentanyl-related deaths among drug addicts in Sweden. Forensic Sci Int 1997; 88: 185-95.

15. Lankenau SE, Teti M, Silva K, Bloom JJ, Harocopos A, Treese M. Patterns of prescription drug misuse among young injection drug users. J Urban Health 2012; 89: 1004-

16. Psychotropic Substances. Statistics for 2007. Report from the International Narcotics Control Board 2008. United Nations 2009: 39.

17. Knaus WA, Draper EA, Wagner DP, Zimmerman JE. Apache ii: A severity of disease classification system. Crit Care Med 1985; 13: 818-29.

\section{ENGLISH SUMMARY}

\section{Injecting drug abuse: Survival after intensive care admission and forensic toxicology reports at death}

Kristinn Sigvaldason', Thoroddur Ingvarsson', Svava Thordardottir ${ }^{2}$, Jakob Kristinsson ${ }^{3}$, Sigurbergur Karason ${ }^{1,3}$

Introduction: Injecting drug abuse is a worldwide problem with serious consequences for the individual and for society. The purpose of this study was to gather information on the most serious complications of injecting drug use from two perspectives, intensive care admissions and forensic toxicology reports.

Material and methods: Firstly, intensive care admissions related to injecting drug abuse during a five year period were reviewed for demographics, complications and 5 year survival. Secondly, information from forensic toxicology reports regarding deaths amongst known injecting drug abusers were gathered for the same period.

Results: A total of 57 patients with a history of active injecting drug use were admitted to intensive care or approximately $1 \%$ of admissions, most often for overdose (52\%) or life threatening infections (39\%).
Median age was 26 , males were $66 \%$. The most common substances used were prescription drugs. Hospital mortality was $16 \%$ and five year survival $65 \%$. Average time from hospital discharge to death was $916 \pm 858$ days. During the study period 38 deaths of individuals with a history of injecting drugs were identified by forensic toxicology reports or $4.1 / 10^{5}$ population/year (age 15-59). Cause of death was most often overdose (53\%), usually from prescription opiates but multiple drug use was common.

Discussion: The life expectancy of injecting drug abusers after intensive care admission is substantially decreased, with $35 \%$ death rate within five years. A widespread use of prescription drugs is of concern. Injecting drug abuse seems to be a similar health problem in magnitude in Iceland as in other Scandinavian countries. 